\title{
Application of Asset Management System Using Barcode (Case Study PT. Indonesia Toray Synthetics)
}

\author{
Ria Wulandari*1, Yuni Roza ${ }^{2}$, Naufal Fadhil Alwarits ${ }^{3}$ \\ ${ }^{1,3}$ Program Studi Teknik Informatika Universitas Raharja, ${ }^{2}$ Program Studi Sistem \\ Informasi Universitas Raharja \\ Email: *11 wulandari@ raharja.info, ${ }^{2}$ yuni.roza@ raharja.info, ${ }^{3}$ naufal.fadhil@ raharja.info
}

\begin{abstract}
Asset Management at PT. Indonesia Toray Synthetics is still done manually, it also burdens admin in inputting and searching for asset data. The utilization of information technology in managing the asset management system will greatly assist PT. Indonesia Toray Synthetics by scanning items using barcodes, displaying the history of incoming and outgoing goods, and being able to manage asset management reports based on certain periods in real time. In making this system and research, the writer uses the SWOT (Strengths, Weaknesses, Opportunities \& Threats) method, and UML (Unified Modeling language) for system design oriented which has been implemented in the PHP (Hypertext) programming language and Sublime Text applications. With the application of this asset management system, it will be able to facilitate the data collection and data search of assets as well as to control the stock rotation of goods in the company.
\end{abstract}

Keywords — Asset Management, Company, Application, Barcode

\section{INTRODUCTION}

Technology is inseparable from human life and is always dynamic. The development of increasingly modern times and increasingly sophisticated technological developments make humans feel pampered and familiarized with existing technology. Therefore, along with technological developments, more and more facilities are becoming more sophisticated to be utilized in various fields. At this time, computers can be used to design various systems needed to make information that is very useful for people who use that information. Therefore, the use of information technology in managing asset management systems will be very helpful in overcoming problems. Computers have become part of human evolution towards technology. One form of technology development is a barcode system that can be used as an alternative to solving problems. Barcode is a code that forms a set of bar-shaped lines (bars) that have different thicknesses ${ }^{[10]}$. This requires optimizing the use of technology in this case the computers againts data processing by designing an information system that is applied into the programming language ${ }^{[5]}$. The development of computerization can make it easier for employees to complete their work. With the information system, data processing can be faster, more efficient, and more accurate ${ }^{[1]}$.

In line with that, the writer found a problem in PT Indonesia Toray Synthetics related to managing inventory data. Managing data that is still manual is said to hamper the work implementation process. Thus the warehouse staff requires a long time to record reports of incoming and outgoing goods. ${ }^{[9]}$ For that, companies need to apply the concept of inputting data for the receipt and release of goods into the inventory system quickly, accurately and can be accounted for ${ }^{[3]}$. In the process of inputting and processing asset data at PT Indonesia Toray Synthetics (ITS), accuracy and speed of system performance are made in a complete, detailed and in real time manner to facilitate employee performance. At PT Indonesia Toray Synthetics (ITS), especially in the part of asset management systems is still semi- 
computerized and not yet running in real time, so if searching for any data, it will be difficult and need a more time. However, with a computerized system, the existing problems can be solved.

\section{RESEARCH METHOD}

\section{A. Analysis Method}

Data analysis is one important step in order to obtain research findings. This is because the data will lead us towards scientific findings, when analyzed with appropriate techniques. System analysis is carried out using the SWOT (strengths, weaknesses, opportunities, threats)Analysis Method that is the strengths, weaknesses, opportunities, and which become threats. SWOT analysis can be applied by analyzing and sorting out various things that affect the four factors, then applying it in the SWOT matrix image ${ }^{[7]}$. The following is a running system analysis table using the SWOT method:

Table 1. Identification Table of the Running System Using the SWOT Method

\begin{tabular}{|c|c|c|}
\hline \multirow{3}{*}{ Internal Factor } & Strength & Weakness \\
\hline & $\begin{array}{l}\text { 1. The asset management } \\
\text { system in the warehouse is } \\
\text { now computerized } \\
\text { 2. Having employees who are } \\
\text { competent in their fields. } \\
\text { 3. Computer specifications that } \\
\text { can support the smooth } \\
\text { running of the system. } \\
\text { 4. Financial aspects of a } \\
\text { company that is able to fully } \\
\text { support warehouse operations } \\
\text { in order to achieve company } \\
\text { targets. } \\
\text { The condition of the asset } \\
\text { management warehouse that } \\
\text { is clean, neat, comfortable } \\
\text { and healthy. }\end{array}$ & $\begin{array}{l}\text { 1. The system that is currently running } \\
\text { is still using Ms. Excel for inputting } \\
\text { incoming and outgoing goods, and } \\
\text { paper as an archiving media } \\
\text { 2. A routine human resource } \\
\text { improvement program has not been } \\
\text { implemented, specifically in the field } \\
\text { of asset management administration. } \\
\text { 3. No periodic employee rotation by } \\
\text { management can result in burnout. } \\
\text { 4. No hardware updates are made to } \\
\text { support the smooth operation of the } \\
\text { company. } \\
\text { 5. Lack of asset management analysis } \\
\text { between the availability of goods in } \\
\text { the warehouse and the needs of the } \\
\text { goods in the warehouse. }\end{array}$ \\
\hline & Opportunities & Threat \\
\hline External Factors & $\begin{array}{l}\text { 1. Speed of service and efficient } \\
\text { running system increase } \\
\text { customer satisfaction and } \\
\text { company reputation. } \\
\text { 2. The Increased demand for } \\
\text { goods. } \\
\text { 3. The high level of availability } \\
\text { of goods offered by the } \\
\text { market. } \\
\text { 4. The increased purchasing } \\
\text { power. } \\
\text { 5. The number of similar } \\
\text { companies is relatively small. }\end{array}$ & $\begin{array}{l}\text { 1. Loss of customer if the goods } \\
\text { ordered are out of stock because the } \\
\text { stock data on the system does not } \\
\text { match the number of goods in the } \\
\text { warehouse. } \\
\text { 2. The vulnerability of malware threats } \\
\text { to existing Excel files. } \\
\text { 3. Government programs that require } \\
\text { companies to minimize the use of } \\
\text { paper. } \\
\text { 4. The high price of paper. } \\
\text { 5. Government regulations that have } \\
\text { high economic costs. }\end{array}$ \\
\hline
\end{tabular}


The Following is a SWOT matrix table to find the best opportunities of the system to be built:

Table 2. SWOT Matrix Table

\begin{tabular}{|c|c|c|}
\hline I & Strength & Weakness \\
\hline \multirow{3}{*}{ 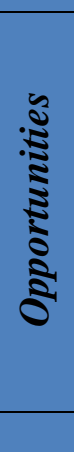 } & SO & WO \\
\hline & $\begin{array}{l}\text { Develop an asset management } \\
\text { system to make it easier for related } \\
\text { employees to search or view } \\
\text { available stock items accurately. }\end{array}$ & $\begin{array}{l}\text { Build a more efficient asset management } \\
\text { system that can cover all files in a } \\
\text { computerized warehouse in real time. }\end{array}$ \\
\hline & ST & WT \\
\hline$\frac{k}{2}$ & $\begin{array}{l}\text { Create an asset management system that } \\
\text { can make it easier for employees to } \\
\text { import and export data in the form of } \\
\text { Ms. Excel files and pdf, and produce } \\
\text { more accurate results. }\end{array}$ & $\begin{array}{l}\text { Build a real-time asset management } \\
\text { system that can operate easily, quickly, } \\
\text { and more efficiently. }\end{array}$ \\
\hline
\end{tabular}

\section{B. System Design Method}

After the analysis method has been implemented, the next stage is the system design method. To complete this report, the writer designed the system using the Visual Paradigm for UML 8.0 Enterprise Edition program which is a software development based on Oriented Object, Xampp Package to support web-based programming that includes MySQL, Apache and PHP MyAdmin, Bootstrap as source code template, Sublime Text as a code editor, and Barcode to PC as a Barcode code scanner application using an Android smart phone as a scanner. 


\section{Use CaseDiagram of The Current System}

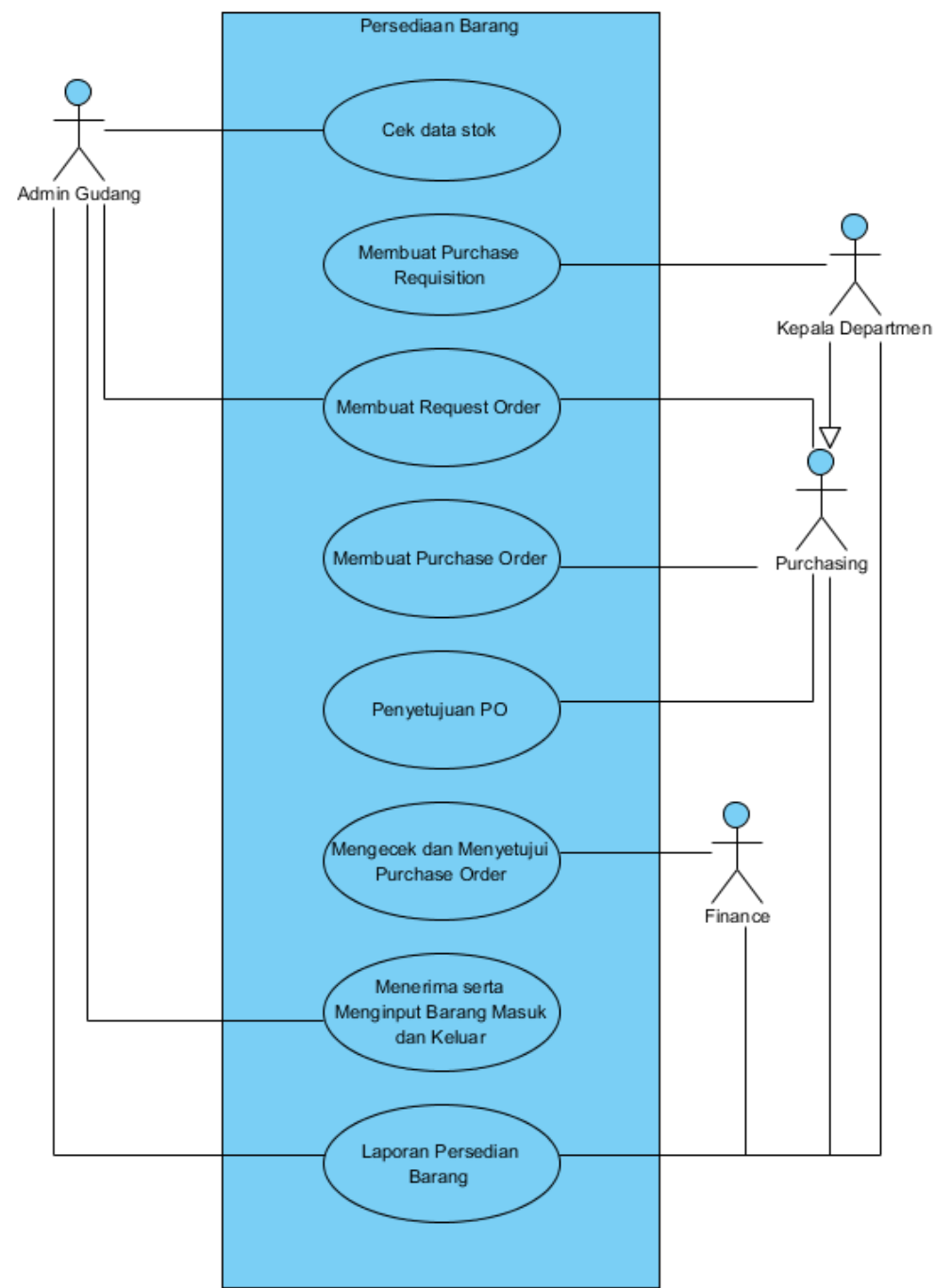

Figure 1. Use Case of Asset Management

Based on the picture above, it can be concluded as follows:

1) There is 1 asset management system

2) There are 4 Actors, namely: Warehouse Admin, Head of Department, Purchasing, and Finance

3) There are 8 cases conducted by the Actor, namely: Check Stock Data, Make a Purchase Requisition, Make a Request Order, Make a Purchase Order, Approval of Purchase Order, Check and Approve Purchase Orders, Receive and Input Goods in and Out, and Asset Management Reports

\section{Literature Review}

1) Research conducted by Izak Habel Wayapai 2017 concerning "Utilization of Barcode Technology in Making Employee Attendance System Applications at the Merauke Regional RRI LPP Office" ${ }^{110]}$. The most important obstacle is when recording a lot of data resulting in frequent errors in recording data. From the above problems, the authors chose barcode technology as an alternative problem solving, barcode is a code in the form of a set of bar-shaped lines (bars) that have different thicknesses. Each line symbolizes a number or letters that have been arranged in such a way, which can be 
read using a tool (barcode reader). Barcodes are drawn in the form of bars and thick, thin black spaces arranged in horizontal rows. To help with the manual reading, numbers or letters are usually listed below the line code. At present Barcodes consist of 2 types namely: Linear Code (1 Dimensional Barcode) and Matrix Code (2 Dimensional Barcode).

2) Research conducted by Agustian Noor, Herpendi, Radna Rurmalina 2018 concerning "Planning and Development of Goods and Sales Stock Applications at UPT. Entrepreneurship Using Barcodes and Smart Cards " ${ }^{[4]}$. This study generally aims to produce a system that can manage data on inventory and sales at the UPT Entrepreneurship State Polytechnic Land of the Sea. The proposal of this research is focused first on building goods and sales inventory applications by adding a touch of barcode technology and smart cards that can provide convenience in managing data items. Application is used during the transaction process and inventory management of goods, from the process of incoming goods to goods out with the method used that is closer or placing a barcode on the item code and smart card or RFID card on the RFID card reader owned by a registered customer, then directly the application receive data on the barcode and the card. $\mathrm{g}$ and smart card or RFID card on the RFID card reader owned by a registered customer, then the application directly accepts the data contained in the barcode and card.

3) Research conducted by Phindile Ndlala and Charles Mbohwa in 2017 from the International Journal of the Department of Quality and Operations Management of the University of Johannesburg under the title "The Application Inventory Control Systems In Warehouse"[6]. This study describes the Re-order point (ROP) tracks the amount of stock remaining each time a withdrawal is made to decide whether to order or not order. ROP determines the level at which action must be taken to refill stock of goods. Fastmoving products are ordered when the inventory level runs out, ensuring the stock remains fresh at all times.

4) Research conducted by Hong Shen, et al. In the title "A Case Study of Inventory Management in a Manufacturing Company in China" in the Nang Yan Business Journal $(2017)^{[2]}$. In this paper, we focus on inventory management in manufacturing companies in Indonesia and China. This study aims to find out the main factors that influence inventory management practices, investigate efficient and effective inventory management approaches, and examine their impact, supplier cooperation in improving supply chains. The case study approach is used to identify key factors that influence inventory management in a factory. Efficient and effective inventory management practices are derived from case studies and can provide practical guidance for foreign producers in China. This study provides a valuable tool for identifying key factors in inventory management that can be applied to similar problems that manufacturers actually face.

5) Research conducted by Ahmad Rifai (2016). This study is entitled "Designing a WebBased Material Inventory Information System at PT. Surya Graha Mandiri Utama"[8]. This study discusses the design of a material stock control information system to make improvements to the old system that has not been running optimally. The author is developing to create a system that is faster, more precise and accurate by using webbased applications. The methodology used is SDLC (System Development Life Cycle) with object-oriented analysis and development approaches ranging from analyzing systems running through UML, conducting elicitation, and describing the proposed system through UML. In addition, a new web-based application design was also produced that could improve operational performance, especially in the warehouse division. Researchers use the PHP programming language used for system development, MySQL as its database design program and Notepad ++ to write system scripts that are built. 


\section{RESULTS AND DISCUSSION}

The proposal or design that will be submitted in this paper is to design and create a website-based asset management system in real-time using barcodes, which can facilitate the management and stock of goods that were previously still using a semi-computerized system. There are several kinds of procedures that aim to improve and simplify the system that is running now and will look more transparent. The proposed procedure will be illustrated using Use Case Diagrams, Activity Diagrams, Sequence Diagrams, and Class Diagrams.

\section{A. Use Case Proposed System Diagram}

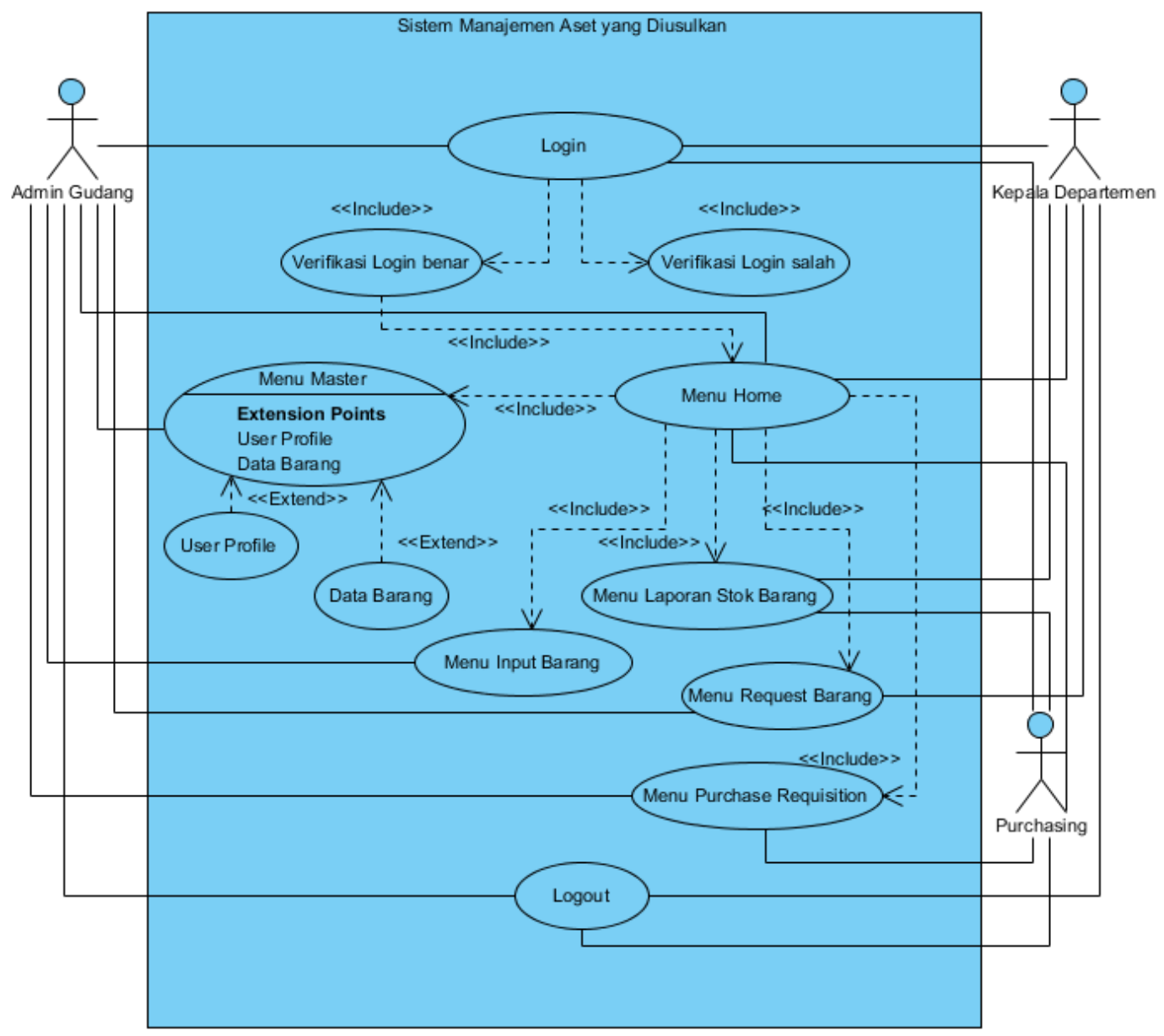

Figure 2. Use Case Diagram Proposed System Diagram

Based on the picture above, it can be concluded as follows:

1) There is 1 system that covers the entire proposed asset management system

2) There are 4 actors, namely: Warehouse Admin, Head of Department, Purchasing, and Finance.

3) There is 1 Extension Point, namely: Home

4) There are 3 include, namely: Login, Verification Login and Logout

5) There are 5 extend, namely: Profile, Input of Goods, Stock of Goods, Reports and Notifications 
B. Design the proposed Asset Management System Application Display

1) Login Menu Display

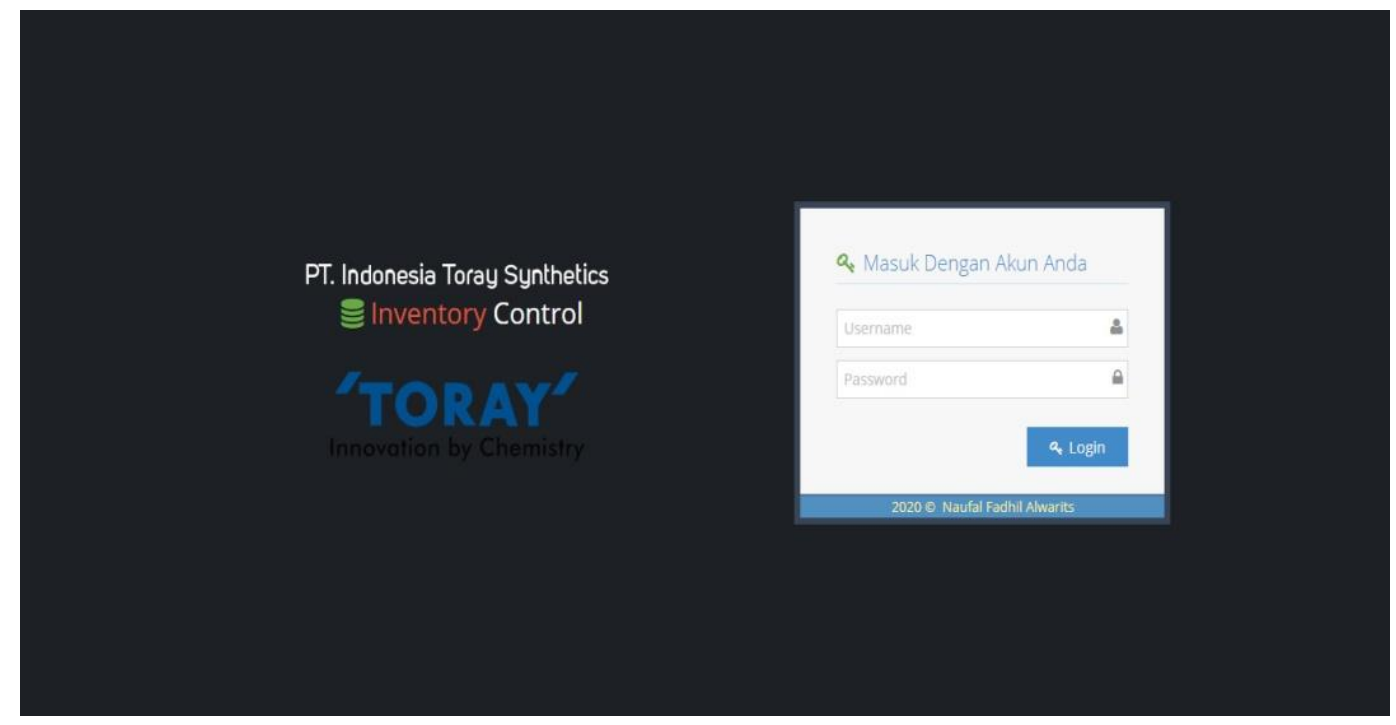

Figure 3. Login Menu Display

2) Home Menu Display

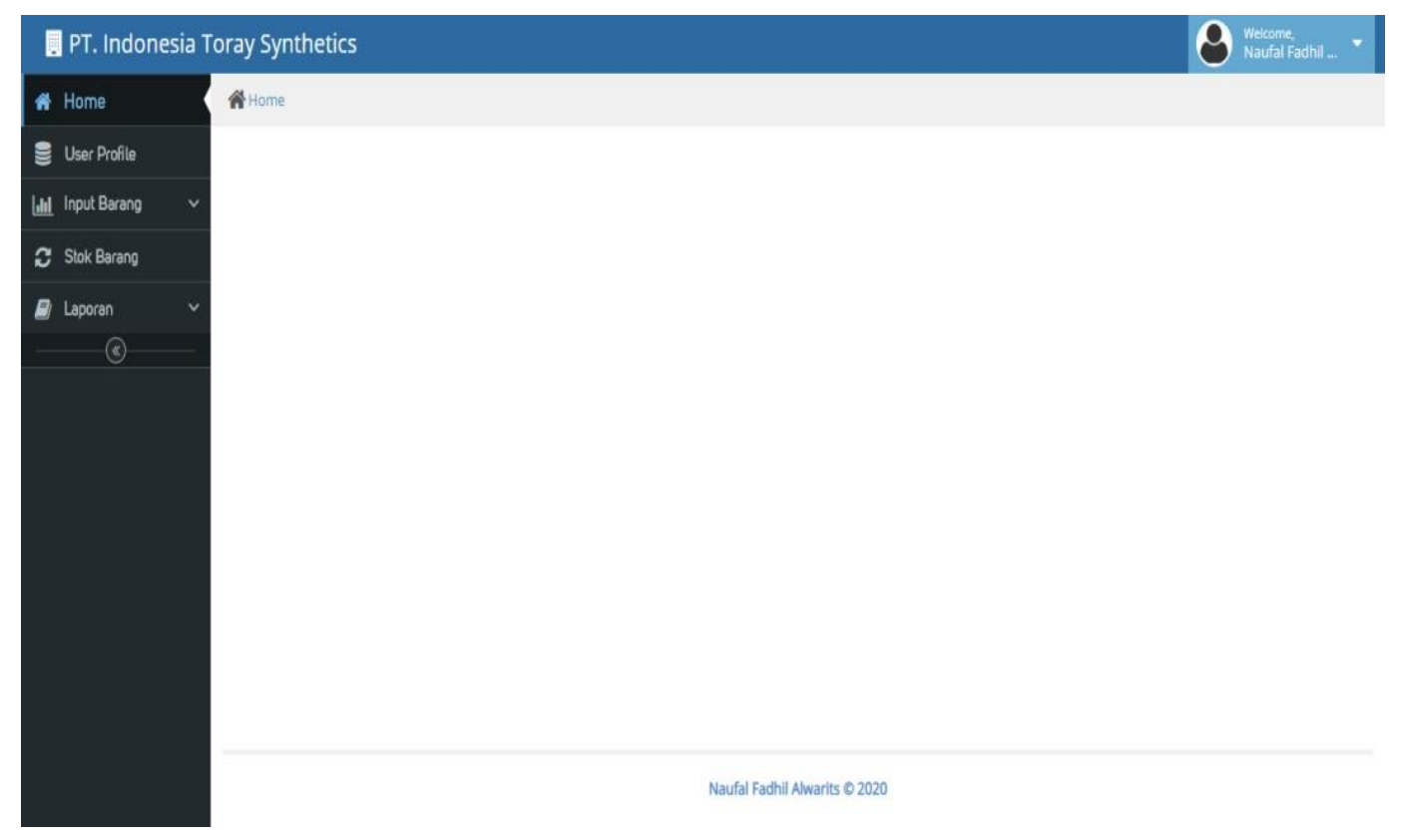

Figure 4. Home Menu Display 
3) Display User Profile

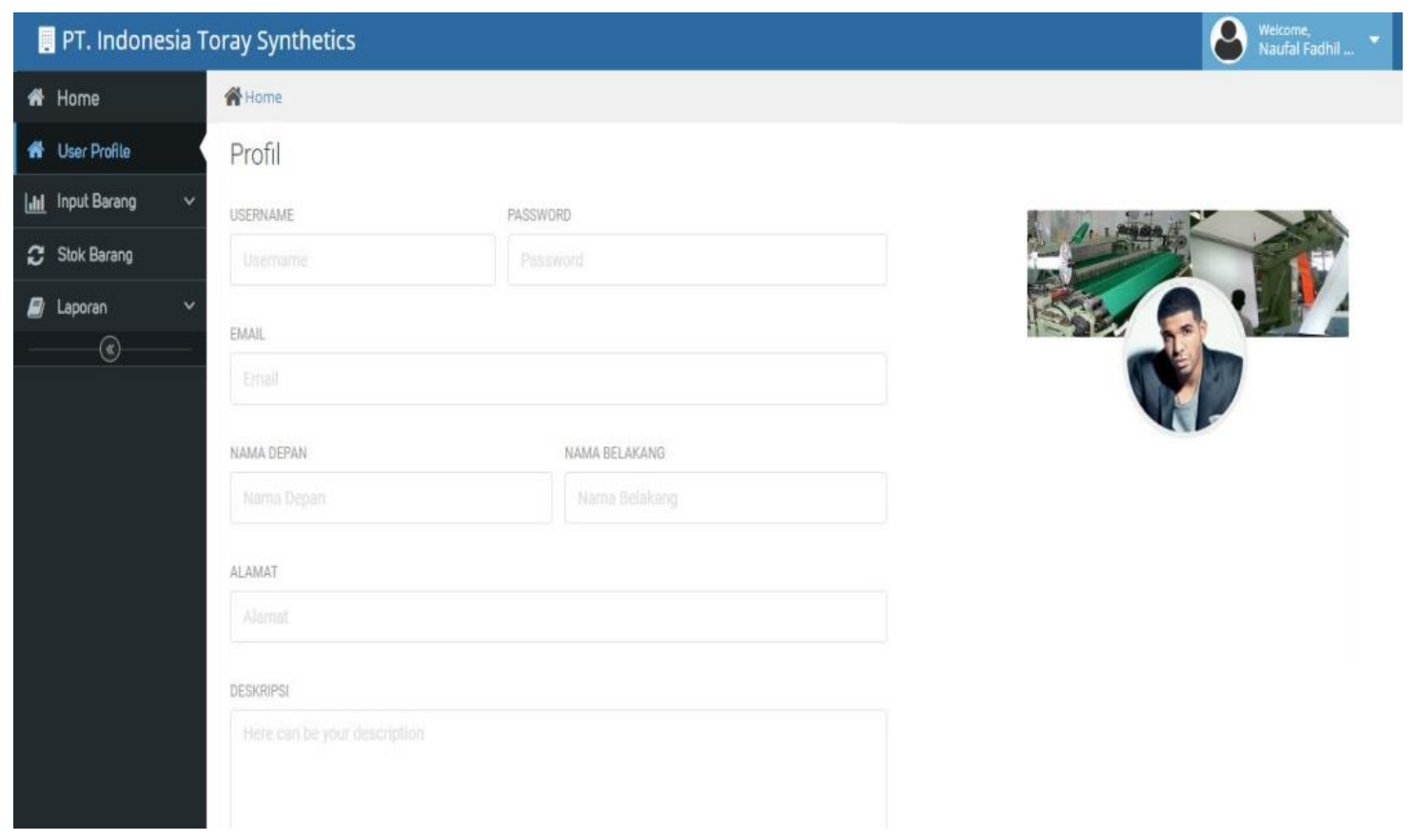

Figure 5. Display User Profile

4) Display Input Entered Items

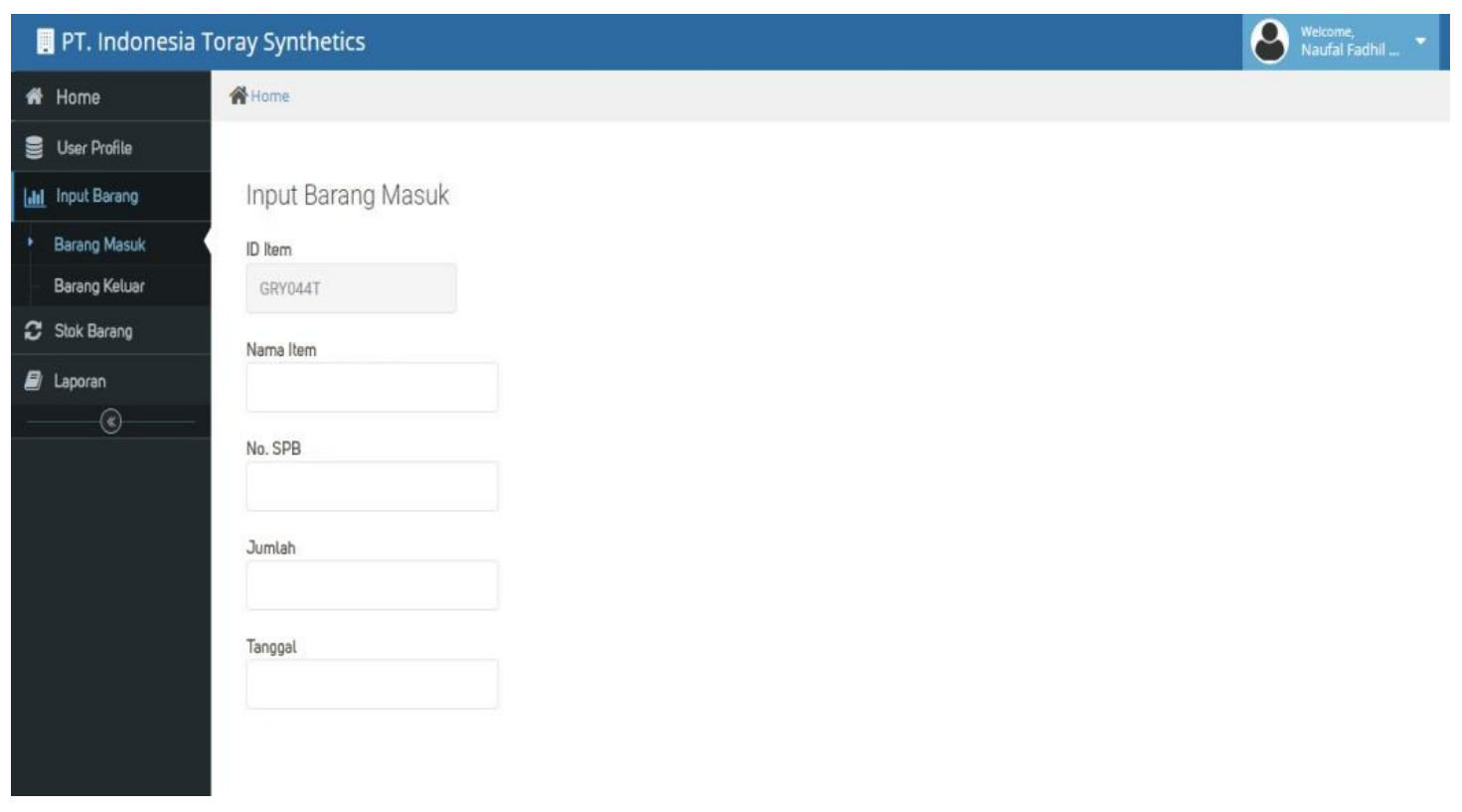

Figure 6. Display Input Entered Items 
5) Display Item Exit Input menu

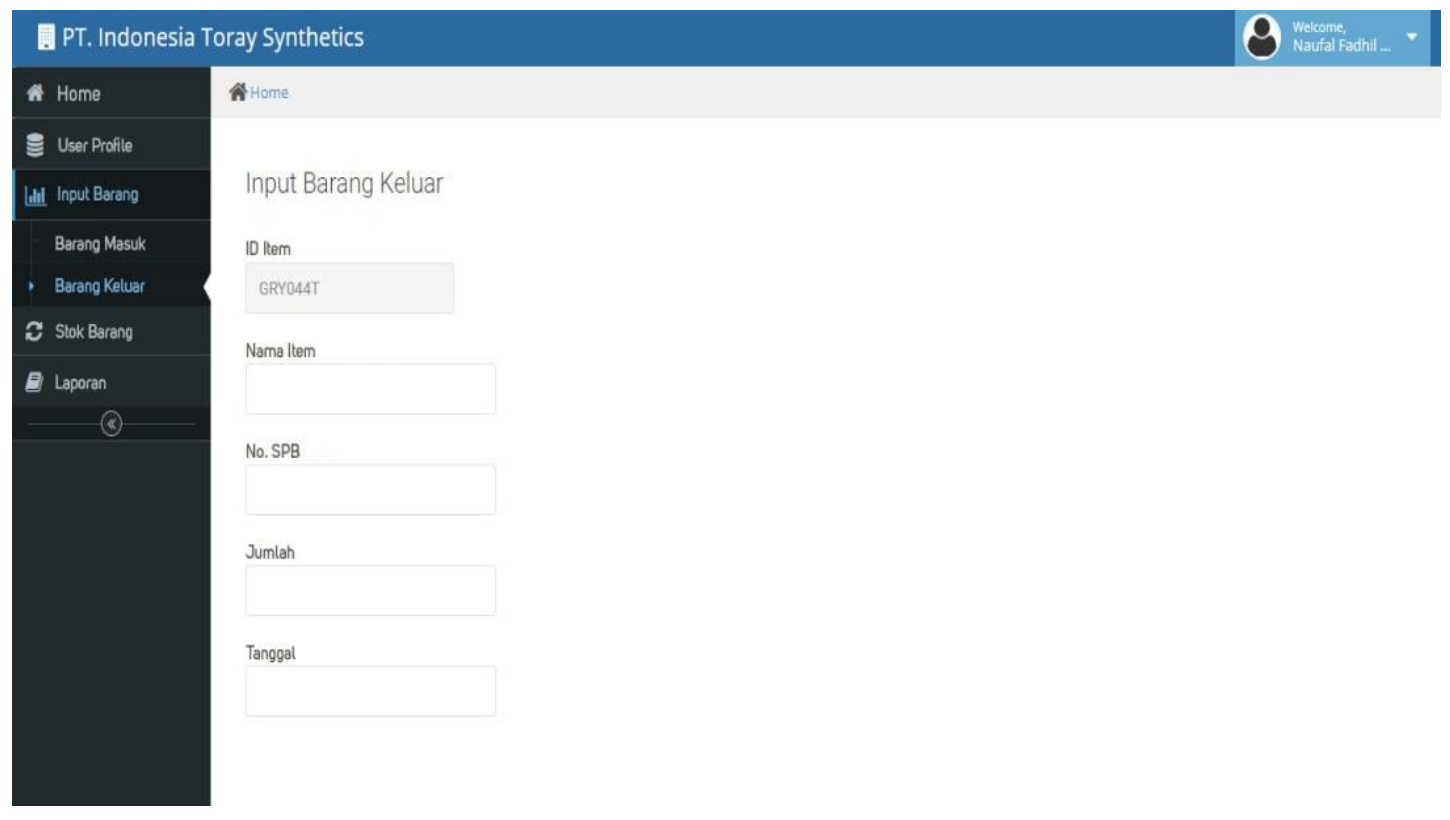

Figure 7. Display Item Exit Input Menu

6) Display Item Stock Items

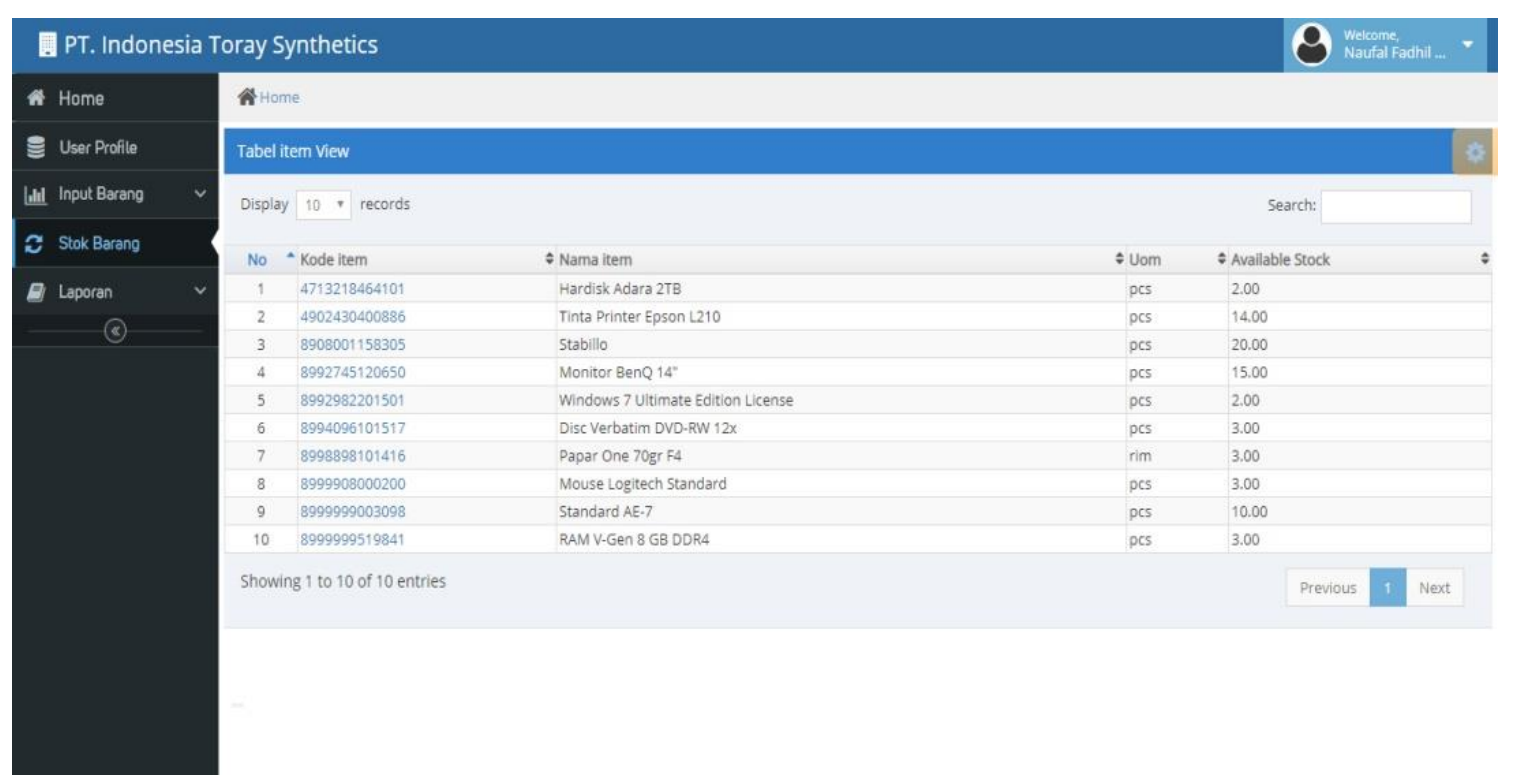

Figure 8. Display Item Stock Items 


\section{7) Report Menu Display}

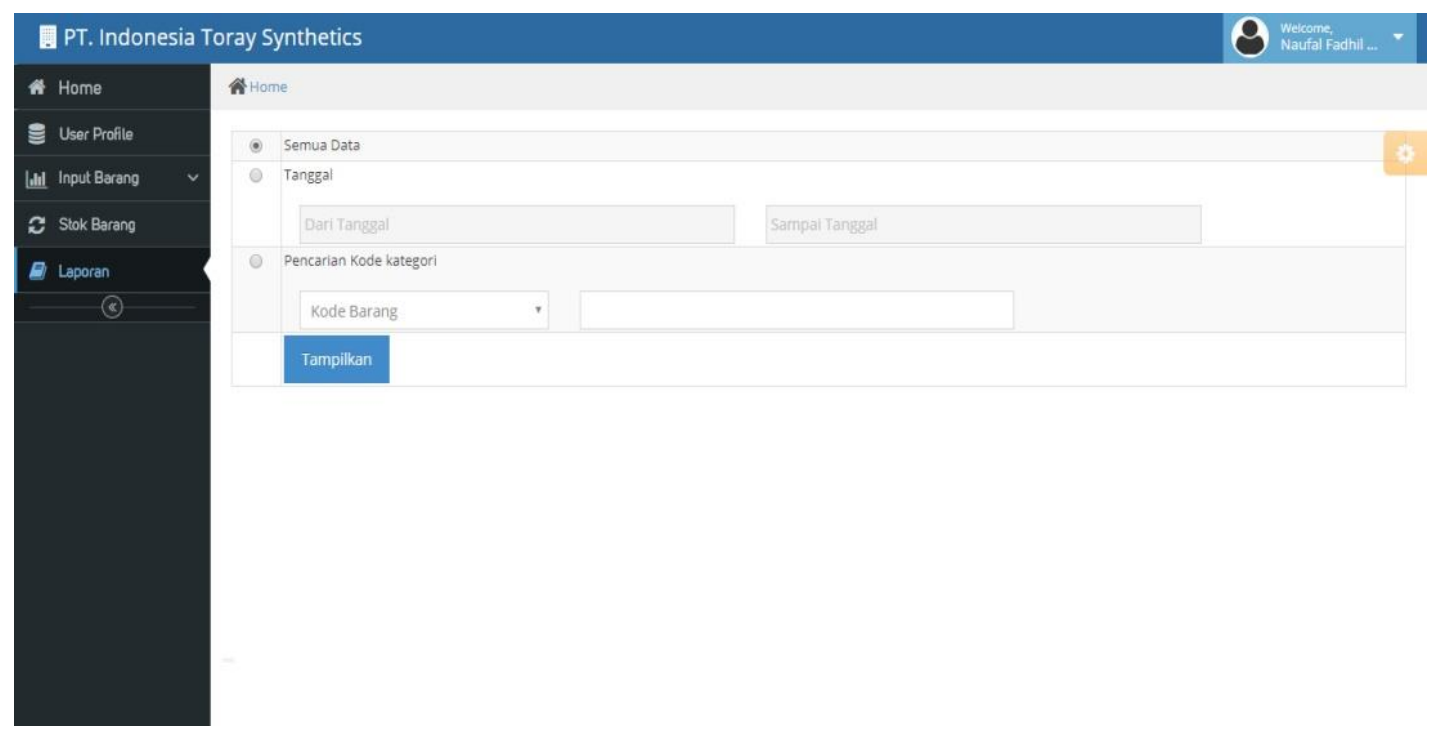

Figure 9. Report Menu Display

\section{CONCLUSION}

Based on the analysis of existing problems, especially in the asset management system at PT. Indonesia Toray Synthetics, the writer can provide the following conclusions:

1) From the system that is already running, it is still manual with the system still using Microsoft Office Excel for inputting data of incoming and outgoing goods.

2) The system that is being used has not been able to present data accurately, so to look for data on incoming or outgoing goods requires a quitelong time.

3) Because the asset management system that is being used at PT. Indonesia Toray Synthetics still cannot run effectively and efficiently, a system that can be run in real time, easily, effectively and efficiently will be built.

\section{SUGGESTED}

The suggestions from the writer to further improve the asset management system at PT. Indonesia Toray Synthetics, as follows:

1) Develop a computerized asset management system based on a website that can run optimally so that it can produce fast and accurate data in real time.

2) Create an asset management system that can input incoming and outgoing goods by scanning those items using barcodes, displaying the history of incoming and outgoing goods, and managing asset management reports based on a certain period.

3) Change the system that is currently not running effectively because it still uses Microsoft Office Excel and manual data collection by making a system that can be used easily, effectively and efficiently so as to shorten the time in the process of finding and collecting goods accurately, quickly, and in real time. 


\section{REFERENCES}

[1] Himawan, Tri Wahyu. 2017. "Perancangan Sistem Informasi Persediaan Barang Pada Unicorn Toys Semarang”. Skripsi, Fakultas Ilmu Komputer. http://eprints.dinus.ac.id/id/eprint/12974

[2] Hong Shen, Qiang Deng, Rebecca Lao, dan Simon Wu. (2017). A Case Study of Inventory Management in a Manufacturing Company in China. China. Nang Yan Business Journal Vol. 5 No. 1

[3] Indriani, Karlena dan Sudarmadi. 2015. Sistem Informasi Inventory Alat Tulis Kantor (ATK) Menggunakan Metode Waterfall. Jurnal Techno Nusa Mandiri. Vol.12, No.1.

[4] Noor, Agustian., Herpendi dan Radna Nurmalina. 2018. Perencanaan dan Pengembangan Aplikasi Stok Barang dan Penjualan Pada UPT. Kewirausahaan Menggunakan Barcode dan Smart Card. Kalimantan: Jurusan Teknik Informatika, Politeknik Negeri Tanah Laut. Generation Jurnal. Vol. 2, No. 1. e-ISSN: 2549-2233. pISSN: 2580-4952.

[5] Okta, Veza.,dan M.Ropianto. 2017. "Perancangan Sistem Informasi Inventory Data Barang Pada PT. Andalas Berlian Motors". Jurnal Teknik Ibnu Sina(JT-IBSI) Vol. 2 No. 2 ISSN: 2541-2647

[6] Phindile Ndlala, Charles Mbohwa, and Kehinde Sobiyi, 2017. "The Application Inventory Control Systems In Warehouse". International Symposium on Industrial Engineering and Operations Management (IEOM) University of Johannesburg South Africa: 978-1-5090-3924-1

[7] Rangkuti, Freddy. 2015. ANALISIS SWOT: TEKNIK MEMBEDAH KASUS BISNIS. Jakarta: PT. Gramedia Pustaka Utama.

[8] Rifai, Ahmad dan Alit Suryani. 2016. Peran Customer Perceived Value pada Kepuasan Pelanggan Tiket Online. E-Jurnal Manajemen Unud, Vol. 5, No. 6, 2016: 3305-3334. ISSN : 2302-8912.

[9] Ristanto, Joko., Zuriati, dan Dewi Kania W. 2017. APLIKASI INVENTORI DATA OBAT PT HASIL KARYA SEJAHTERA BERBASIS WEB.Lampung.Jurnal Tugas Akhir.

[10] Wayangkau, Izak Habel. 2017. "PEMANFAATAN TEKNOLOGI BARCODE DALAM PEMBUATAN APLIKASI SISTEM KEHADIRAN KARYAWAN PADA KANTOR LPP RRI REGIONAL MERAUKE”. Merauke: Jurnal Ilmiah Mustek Anim Ha. Vol. 6, No.1. 